\title{
ACADEMIA
}

Accelerating the world's research.

\section{The Organosolv Fractionation of Cork Components}

Nereida Cordeiro, Naceur Belgacem

Holzforschung

\section{Need to cite this paper?}

Get the citation in MLA, APA, or Chicago styles
Want more papers like this?

Download a PDF Pack of related papers

Search Academia's catalog of 22 million free papers 


\title{
The Organosolv Fractionation of Cork Components
}

\author{
By Nereida Cordeiro ${ }^{1}$, Carlos Pascoal Neto ${ }^{2}$, Joao Rocha ${ }^{2}$, Mohamed N. Belgacem ${ }^{3}$ and Alessandro Gandini ${ }^{3}$ \\ ${ }^{1}$ Universidade da Madeira, Centro de Investigação em Ciências Agrárias, Funchal, Portugal \\ ${ }^{2}$ Universidade de Aveiro, Departamento de Química, Aveiro, Portugal \\ ${ }^{3}$ Ecole Française de Papeterie et des Industries Graphiques, St. Martin d'Hères, France
}

Keywords
Cork
Quercus suber L.
Organosolv fractionation
Ethanol/water extraction
Suberin
FTIR
${ }^{13}$ C NMR

\section{Introduction}

Cork of Quercus suber L. is composed of suberin, a predominantly aliphatic biopolyester, the main cork component contributing to about $40 \%$ of its dry weight, and lignin, polysaccharides and extractives in equivalent amounts (Cordeiro et al. 1998 a). Most of the studies which have been carried out up to now on the quantification and characterisation of cork components involved a range of chemical treatments (Pereira 1988) which were rather severe and could therefore be accompanied by degradation processes. As a consequence, little information is available on details related to the association among different components within the cork morphology. When milder approaches were applied (Marques et al. 1996), the amounts of extracted components were very small and their ensuing characterisation left some uncertainty about their relevance with respect to the main constituents.

Within a general research programme dealing with cork chemistry (Pascoal Neto et al. 1995; Cordeiro et al. 1995; Pascoal Neto et al. 1996; Gil et al., 1997; Cordeiro et al. 1996, 1998 a, b; Lopes et al. 1998) and with the possible exploitation of its components (Cordeiro et al. $1998 \mathrm{a}$; Cordeiro et al. 1999, 2000), we applied the organosolv fractionation techniques to cork in order to achieve a mild and efficient fractionation.

The organosolv technique involves the treatment of lignocellulosic substrates with organic solvent-water media at high temperatures $\left(140-180^{\circ} \mathrm{C}\right)$ in the presence or absence of a catalyst. This type of process has been previously applied extensively to the fractionation of wood components (Lora and Aziz 1985; Pascoal Neto et al. 1994;
Evtuguin et al. 1999). It has been performed with a great variety of solvents using acid (mineral, organic or Lewis acids) or alkaline catalysts (sodium hydroxide or ammonia). The fractions obtained have different characteristics depending on the specific process conditions. In this work, we have fractionated the cork components by an organosolv treatment based on the use of ethanol/water media and characterised the residual cork by FTIR and ${ }^{13} \mathrm{C}$-solidstate NMR.

\section{Materials and Methods}

Cork powder samples were obtained by grinding high-quality reproduction cork kindly supplied by the Champcork Company of Portugal. The composition of this sample was determined by classical methods (Pereira 1988) and found to be: $47 \%$ of suberin, $18 \%$ of lignin, $16 \%$ of polysaccharides and $19 \%$ of extractives (o. d. cork). This powder was extracted sequentially with dichloromethane, ethanol and water in a soxhlet apparatus ( $8 \mathrm{~h}$ for each solvent). The extractive-free cork powder was dried to constant weight and then treated with the solvent mixture in a 4842 PARR stirred reactor working under pressure. Processing conditions were as follows: i) solvent mixture: (ethanol:water, v:v) 0:100, 20:80, 40:60, 50:50, 80:20, 100:0; ii) solvent/cork ratio: $20 / 1$ and 40/ 1 (1/kg); iii) catalyst: none, $0.1 \mathrm{M}$ acetic acid; $0.1 \mathrm{M} \mathrm{H}_{2} \mathrm{SO}_{4} ; 0.05,0.1$, 0.3 and $0.5 \mathrm{M}$ sodium hydroxide; iv) temperature: $110,120,140$ and $160^{\circ} \mathrm{C}$; v) time: $1,2,3$ and 4 hours at constant temperature. After cooking, the reactor was cooled and the solid fraction separated from the black liquor by filtration. The solid residue was then washed with water, dichloromethane and diethyl ether and finally dried to constant weight.

The FTIR spectra were taken with a Mattson 7000 spectrophotometer using the standard $\mathrm{KBr}$ pellet technique. Solid-state ${ }^{13} \mathrm{C}$ NMR spectra were recorded on a Bruker MSL-400 spectro- 
meter at $100.6 \mathrm{MHz}$, at room temperature, with rotors spinning at $5.9 \mathrm{KHz}$. The CP-MAS spectra were recorded with 3 s recycle delay and $1.5 \mathrm{~ms}$ contact time.

\section{Results and Discussion}

\section{Effect of the addition of acid and basic catalysts}

Table 1 shows the results of organosolv treatment of cork with ethanol/water media in terms of the percentage of extracted material. The uncatalysed treatment of cork yielded $14.7 \%$ of dissolved substances. This relatively low yield, compared with those obtained with woody materials (Pascoal Neto et al. 1994), was attributed to the fact that closed cells and the presence of suberin in the cell walls limited the diffusion of the liquid mixture inside the cork structure. The addition of $0.1 \mathrm{M}$ acetic acid increased the yield to only $23.0 \%$ for the same $4 \mathrm{~h}$ and to $27.2 \%$ for $12 \mathrm{~h}$ processing. This modest increase can be explained by the resistance of the cork structure to the attack by (weak) acidic media in contrast to alkaline ones. In fact, the ester bonds in suberin can be readily hydrolysed by bases, as clearly shown by the substantial yield increase to $76.3 \%$ when the same concentration of $\mathrm{NaOH}$ was added to the liquid phase. These results suggest that $\mathrm{i}$ ) suberin is present in cork as a "coating" enveloping the other components and/or ii) suberin is chemically associated with the other components, making it impossible to separate them efficiently without the preliminary hydrolysis of the ester linkages. This conclusion is corroborated by the fact that

Table 1. Processing conditions and results of organosolv fractionations applied to cork of Quercus suber L

\begin{tabular}{|c|c|c|c|c|c|}
\hline Catalyst & Ethanol/water & Temperature $\left({ }^{\circ} \mathrm{C}\right)$ & $\begin{array}{l}\text { Catalyst (M) } \\
\text { Concentration }\end{array}$ & Time (h) & $\begin{array}{l}\text { \% dissolved material } \\
\text { (extracted cork) }\end{array}$ \\
\hline Without & $50 / 50$ & 160 & - & 4 & 14.7 \\
\hline Acetic acid & $50 / 50$ & 160 & 0.1 & 4 & 23.0 \\
\hline \multirow{4}{*}{$\begin{array}{l}\text { Sodium } \\
\text { Hydroxide }\end{array}$} & $\begin{array}{l}0 / 100 \\
20 / 80 \\
40 / 60 \\
50 / 50 \\
80 / 20 \\
100 / 0\end{array}$ & 160 & 0.1 & 4 & $\begin{array}{l}39.4 \\
39.9 \\
45.6 \\
76.3 \\
72.0 \\
69.9\end{array}$ \\
\hline & $50 / 50$ & $\begin{array}{l}110 \\
120 \\
140 \\
160\end{array}$ & 0.1 & 4 & $\begin{array}{l}30.1 \\
41.9 \\
64.6 \\
76.3\end{array}$ \\
\hline & $50 / 50$ & 160 & $\begin{array}{l}0.05 \\
0.1 \\
0.3 \\
0.5\end{array}$ & 4 & $\begin{array}{l}42.6 \\
76.3 \\
85.0 \\
84.4\end{array}$ \\
\hline & $50 / 50$ & 160 & 0.1 & $\begin{array}{l}1 \\
2 \\
3 \\
4\end{array}$ & $\begin{array}{l}35.4 \\
37.3 \\
46.3 \\
76.3\end{array}$ \\
\hline
\end{tabular}

Table 2. FTIR assignments for cork components

\begin{tabular}{|c|c|c|}
\hline Wavenumber $\left(\mathrm{cm}^{-1}\right)$ & & Assignment \\
\hline 3414 & OH stretch & hemicellulose, cellulose, lignin, suberin \\
\hline 2937 & $\mathrm{CH}$ aliph. stretch & suberin, hemicellulose cellulose, lignin \\
\hline 2850 & & suberin, hemicellulose cellulose, lignin \\
\hline 1745 & $\mathrm{C}=\mathrm{O}$ stretch & suberin, hemicellulose cellulose, lignin \\
\hline 1636 & $\mathrm{C}=\mathrm{C}$ stretch & suberin \\
\hline 1603 & & suberin, lignin \\
\hline 1513 & & suberin, lignin \\
\hline 1468 & $\mathrm{CH}$ assym stretch & suberin, hemicellulose, cellulose, lignin \\
\hline 1384 & $\mathrm{CH}$ sym stretch & suberin, hemicellulose, cellulose, lignin \\
\hline 1270 & $\mathrm{CO}$ stretch & suberin, hemicellulose, cellulose, lignin \\
\hline 1164 & $\mathrm{CO}$ assym. stretch & suberin, hemicellulose, cellulose, lignin \\
\hline 1107 & $\mathrm{CH}, \mathrm{CO}$ deform & hemicellulose, cellulose, lignin \\
\hline 1032 & & hemicellulose, cellulose, lignin \\
\hline
\end{tabular}




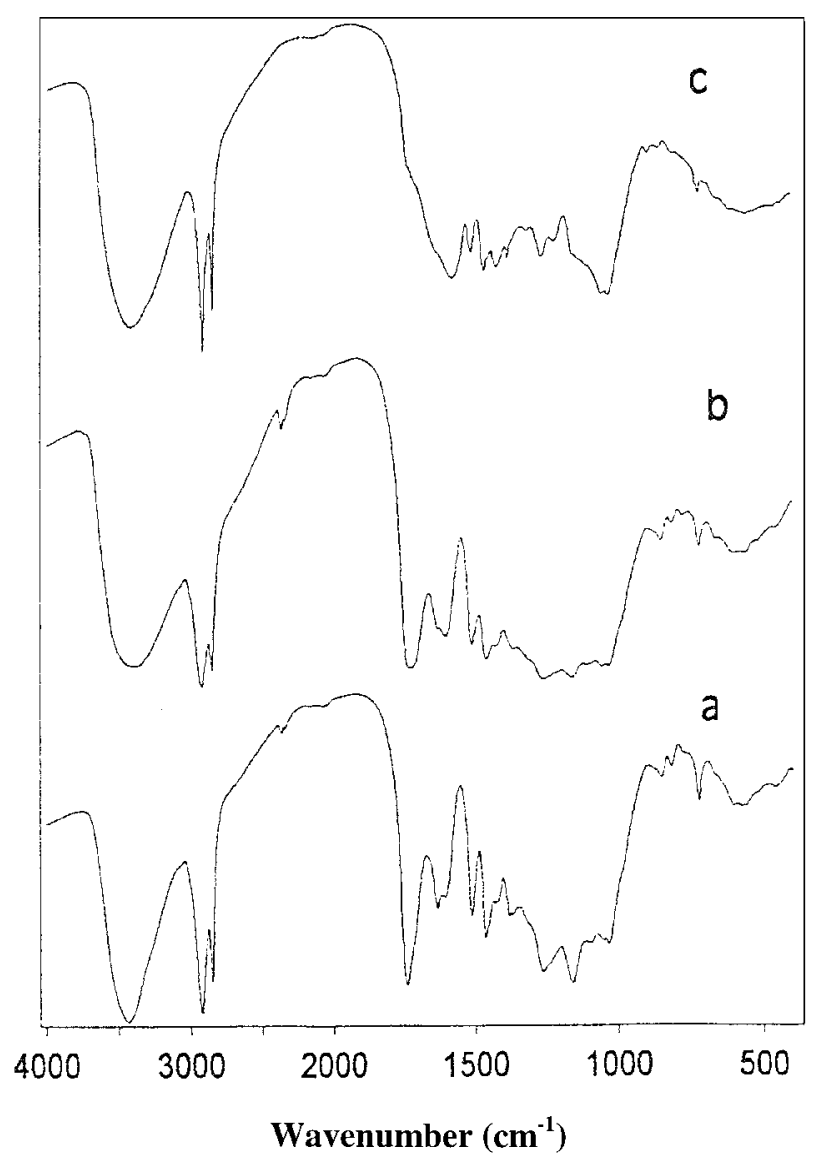

Fig. 1. FTIR spectra of residual cork form (a) uncatalyzed organosolv treatment, (b) in the presence of $0.1 \mathrm{M}$ acetic acid and (c) with $0.1 \mathrm{M}$ sodium hydroxide.

the low percentages of extracted materials with neutral or acidic treatments were composed essentially of saccharidic structures (Cordeiro 1998).

Figure 1 shows the FTIR spectra of residual cork from different processing conditions. Table 2 summarises the assignments of the corresponding bands, based on previous work (Pascoal Neto et al. 1995; Marques et al. 1996).

The spectrum of initial cork (not shown) and that of the residue following the uncatalysed extraction (Fig. 1 a) were very similar. They were characterised by an $\mathrm{O}-\mathrm{H}$ stretch band (ca. $3415 \mathrm{~cm}^{-1}$ ) and a dominant $\mathrm{CH}$ band, with two peaks (ca. $2935-2850 \mathrm{~cm}^{-1}$ ) corresponding to the aliphatic moieties in lignin and carbohydrates, but mostly in suberin components (Table 2). The intense $\mathrm{C}=\mathrm{O}$ stretching band at $1745 \mathrm{~cm}^{-1}$ is characteristic of aliphatic esters in suberin. The $1635-1515 \mathrm{~cm}^{-1}$ region corresponded to an aromatic $\mathrm{C}=\mathrm{C}$ stretch, from aromatic suberin, but mainly from lignin components. The bands at $1468 \mathrm{~cm}^{-1}$ and $1384 \mathrm{~cm}^{-1}$ reflected C-H symmetric and asymmetric deformations, respectively. The region $1270-1032 \mathrm{~cm}^{-1}$ showed C-O stretch and deformation bands in cellulose, hemicelluloses and lignin, although in this region, suberin can also contribute to the absorption with the C-O stretching from its ester groups (Table 2).

In the FTIR spectrum of residual cork obtained in the presence of acetic acid (Fig. 1 b), small changes were observed only at $1745 \mathrm{~cm}^{-1}$ and in the bands corresponding to
Table 3. ${ }^{13} \mathrm{C}$ NMR assignments for cork components

\begin{tabular}{|c|c|}
\hline $\begin{array}{l}\text { Chemical shift } \\
\text { (ppm) }\end{array}$ & Assignment \\
\hline 21 & $\mathrm{CH}_{3}$-COO-, hemicellulose \\
\hline 30 & $\overline{-(}\left(\mathrm{CH}_{2}\right) \mathrm{n}-$, suberin \\
\hline 33 & $-\left(\mathrm{CH}_{2}\right) \mathrm{n}-$, suberin \\
\hline 56 & Ar- $\mathrm{OCH}_{3}$, lignin, $-\mathrm{OCH}_{3}$, hemicellulose \\
\hline $61-62$ & $\begin{array}{l}\mathrm{C} \gamma-\mathrm{OH}, \mathrm{C} \beta \text {-OAr, lignin } \\
\mathrm{C} 6 \text {, cellulose }\end{array}$ \\
\hline 64 & C6, carbohydrate attached to suberin \\
\hline 72 & $\begin{array}{l}\mathrm{C} 2, \mathrm{C} 3, \mathrm{C} 5 \text {, cellulose, hemicellulose } \\
\mathrm{C} 2, \mathrm{C} 3, \mathrm{C} 5 \text {, carbohydrate attached to } \\
\text { suberin }\end{array}$ \\
\hline 75 & $\begin{array}{l}\mathrm{C} 2, \mathrm{C} 3, \mathrm{C} 5 \text {, cellulose, hemicellulose } \\
\mathrm{C} \gamma-\mathrm{OR}, \mathrm{C} \beta-\mathrm{OR} \text {, lignin }\end{array}$ \\
\hline 82 & $\begin{array}{l}\mathrm{C} 4 \text {, carbohydrate attached to suberin } \\
\mathrm{C} 4 \text {, cellulose }\end{array}$ \\
\hline 89 & $\begin{array}{l}\mathrm{C} 4 \text {, cellulose } \\
\mathrm{C} \beta \text {-OR, } \mathrm{C} \alpha-\mathrm{OR} \text {, lignin }\end{array}$ \\
\hline 105 & $\begin{array}{l}\mathrm{C} 1 \text {, carbohydrate attached to suberin } \\
\mathrm{C} 1 \text {, carbohydrates } \\
\mathrm{C} 1 \text {, cellulose } \\
-\mathrm{CH}=\mathrm{CH}-\text {, suberin } \\
\mathrm{G} 2, \mathrm{~S} 2, \mathrm{~S} 6 \text {, lignin }\end{array}$ \\
\hline 114 & $\begin{array}{l}\text { G5, lignin } \\
-\mathrm{CH}-\text {, aliphatic and aromatic, suberin }\end{array}$ \\
\hline $122-126$ & G6, $C \beta$, lignin \\
\hline 130 & $\begin{array}{l}\text { Quaternary } C \text {, aromatic, suberin } \\
\mathrm{C} \alpha \text {, lignin }\end{array}$ \\
\hline 148 & G4, S4, lignin \\
\hline $151-152$ & $\begin{array}{l}\text { Quaternary C, aromatic, suberin } \\
\text { G3, S3, S5, lignin }\end{array}$ \\
\hline 173 & $\begin{array}{l}\text {-COO-, suberin } \\
\overline{\mathrm{CH}} 3-\mathrm{COO}-, \text { hemicellulose }\end{array}$ \\
\hline
\end{tabular}

C-O stretch (1270 and $\left.1164 \mathrm{~cm}^{-1}\right)$. After the alkaline treatment, the FTIR spectrum (Fig. $1 \mathrm{c}$ ) showed more significant differences, since the carbonyl band was reduced to a small shoulder at $1745 \mathrm{~cm}^{-1}$, mainly from suberin. The presence of unremoved suberin was confirmed by the 2937 and $2850 \mathrm{~cm}^{-1}$ bands arising from aliphatic sequences. The increase in the bands at 1107 and $1032 \mathrm{~cm}^{-1}$, relative to those at 1270 and $1164 \mathrm{~cm}^{-1}$, suggested that lignin had been more largely removed in comparison to carbohydrate components.

The above conclusions were confirmed by the ${ }^{13} \mathrm{C}$ NMR spectra of the same residues, as shown in Figure 2 (Table 3 gives the corresponding assignments). The analysis of these spectra was conducted on the basis of previous work reported for wood and other plant systems (Zlotnik-Mazoni and Stark 1988; Garbow et al. 1989; Stark and Garbow 1992). The most intense peak at 30 and $33 \mathrm{ppm}$ in the spectrum of the initial cork (Fig. 2 a) corresponded to aliphatic $\mathrm{CH}_{2}$ groups in suberin. The signal at $56 \mathrm{ppm}$ resulted mainly from lignin, but hemicellulose $-\mathrm{OCH}_{3}$ groups also contributed in small amounts to this signal. The presence of small amounts of hemicelluloses was confirmed by the signal at $21 \mathrm{ppm}$. The peak at $56 \mathrm{ppm}$ was used to monitor the extraction of lignin. The peaks at $61-105 \mathrm{ppm}$ arose from overlapping signals of carbohydrates and lignin aliphatic carbons. The resonances in the $105-148 \mathrm{ppm}$ region were attributed to 


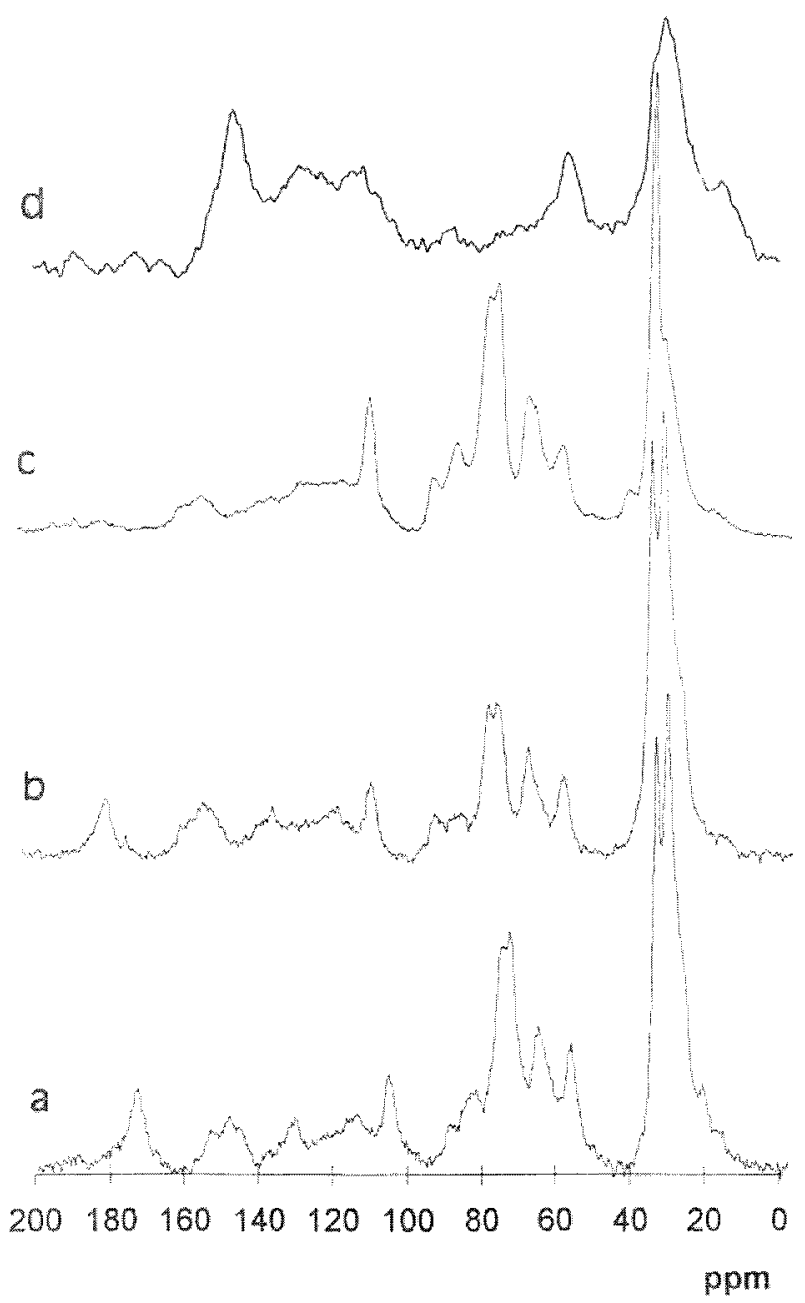

Fig. 2. ${ }^{13} \mathrm{C}$ NMR spectra of residual cork from (a) uncatalyzed organosolv treatment, (b) in the presence of $0.1 \mathrm{M}$ acetic acid, (c) with $0.1 \mathrm{M}$ sodium hydroxide and (d) with $0.1 \mathrm{M}$ sulphuric acid.

unsaturated and aromatic carbons from lignin and/or suberin and the peak at 151-152 ppm to quaternary ring carbons. Finally, the carbonyl signal at 173 ppm confirmed the presence of acetyl groups from suberin and hemicelluloses.

The uncatalysed process gave a residue whose NMR spectrum was very similar to that of the untreated cork (Fig. 2 a), whereas the addition of acetic acid gave rise to significant differences (Fig. 2 b). The peak at 21 ppm disappeared, suggesting the thorough extraction of the acetylated hemicellulose component. The relative decrease in the intensity of the 72 and $82 \mathrm{ppm}$ peaks indicated the partial extraction of polysaccharides (cellulose and hemicelluloses). The comparatively modest extraction of lignin was confirmed by the small decrease in the 56 and 151-152 ppm peaks. Finally, the characteristic peaks of suberin remained unperturbed. These observations confirmed that weak acidic conditions are not favourable to suberin extraction, but work better to remove hemicellulose, cellulose and lignin components (Pereira 1988).

In basic conditions, the changes in the NMR spectrum of the residue (Fig. 2 c) were more drastic, since the peak at 30 ppm showed a large decrease, the peak at 173 ppm disappeared and the peaks at 56 and 114-152 ppm decreased in comparison with those in the $64-105$ ppm region. These results corroborated the conclusions drawn from the FTIR spectra, as indeed expected from the well-known fact that a basic medium favours the predominant extraction of suberin and lignin components (Pereira 1988).

A relevant aspect of this part of our study was the permanence of polysaccharide peaks as well as methylenes resonances at $33 \mathrm{ppm}$ in residual cork, even with high alkaline concentrations $(0.5 \mathrm{M} \mathrm{NaOH})$ (Fig. 7). This suggests that these methylene groups were linked to the carbohydrate/lignin matrix by bonds resistant to that particular medium, i.e., probably ether bonds. This also suggests that the other methylenes groups resonating at 30 ppm were part of COO ester moieties (173 ppm), and could thus be readily removed by alkaline hydrolysis or base-catalysed transesterification with ethanol. This result seems consistent with previous work on cork molecular dynamics (Gil et al. 1997; Lopes et al 2000) in which it was proposed that the less mobile methylene groups in suberin aliphatic chains, resonating at $33 \mathrm{ppm}$, were situated near the linkage to carbohydrate/lignin matrix, probably involving carbohydrate $\mathrm{C}_{6}$ and $\mathrm{C}_{\beta}-\mathrm{OR}$ and/or $\mathrm{C}_{\alpha}$-OR lignin groups. The more mobile $\mathrm{CH}_{2}$ groups, resonating at 30 ppm, were those present in the same suberin chains, but far from the interpolymer junctions.

With the aim of increasing the extent of extraction in acidic conditions, a strong mineral acid was tried in conjunction with the ethanol/water mixture in the same conditions employed for the experiments with $\mathrm{NaOH}$. When $0.1 \mathrm{M}$ sulphuric acid was added as a catalyst, the yield of solubilised materials reached $76.0 \%$. The FTIR spectrum of the residue showed features which clearly indicated that a substantial proportion of lignin remained unextracted. Conversely, most of the ester moieties were removed by this treatment.

The solid state ${ }^{13} \mathrm{C}$ NMR spectrum (Fig. $2 \mathrm{~d}$ ) of this residue, compared with that of initial cork, displayed the following differences: i) a significant decrease in the aliphatic $\mathrm{CH}_{2}$ signal at 30 and the disappearance of the $33 \mathrm{ppm}$ peak, resulting from suberin extraction; ii) whereas the signal at $55 \mathrm{ppm}$, corresponding to methoxy carbons, was still present, the peaks at 64,72 and 82 ppm disappeared, indicating that lignin had not been extracted extensively (as also shown by the FTIR spectrum), but that polysaccharides had been removed; iii) the vanishing of the signal at $172 \mathrm{ppm}$, corresponding mostly to COO groups in suberin; iv) the set of peaks between 110 and 160 ppm, corresponding to lignin aromatic groups, preserved relatively intense signals, particularly at $145 \mathrm{ppm}$, corroborating the evidence related to the presence of lignin in this residue.

Although the use of a strong acid provided a much higher extraction efficiency than weak ones, we also found that the severity of this treatment was excessive in terms of suberin degradation (Cordeiro et al. 2000). Since our main objective beyond these extractions was the possible exploitation of suberin as a source of polymeric materials (Cordeiro et al. 1997, 1999), it was decided to pursue this 


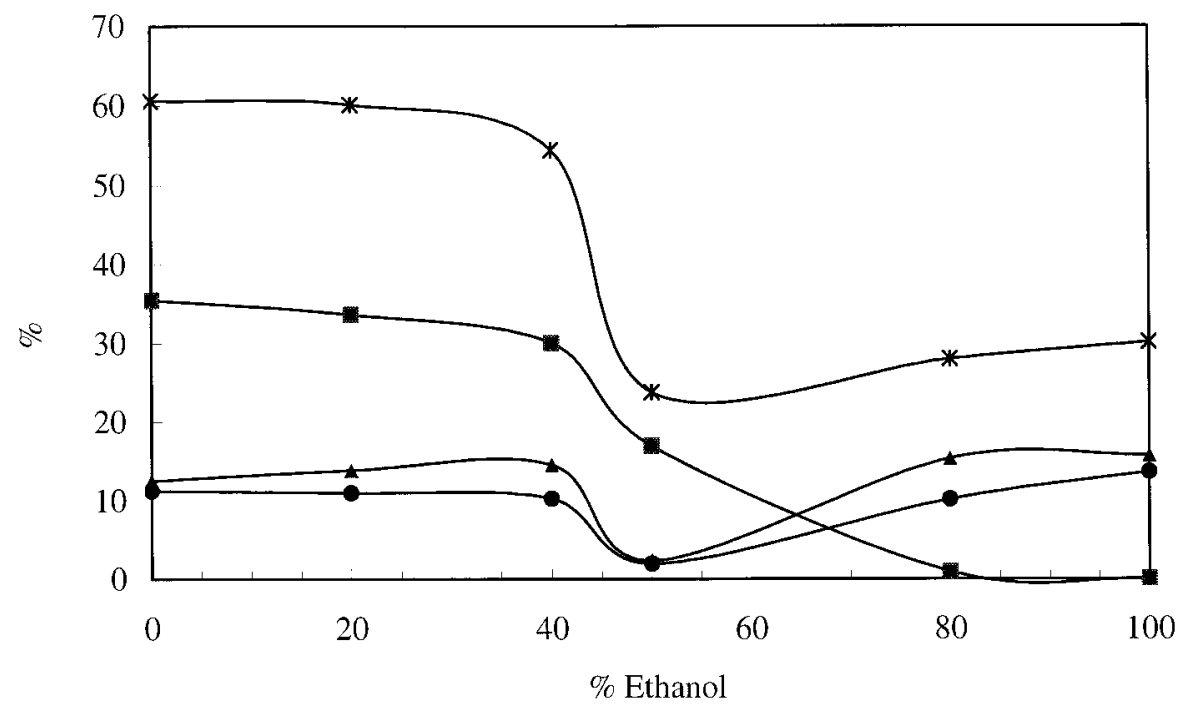

Fig. 3. Variation in the percentage of dissolved material and residual components in cork after organosolv treatments carried out at $160{ }^{\circ} \mathrm{C}$ for $4 \mathrm{~h}$, with variable ethanol/water ratios, $0.1 \mathrm{M}$ sodium hydroxide and a liquor ratio of 40:1.

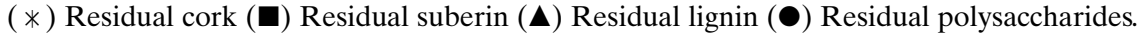

investigation only with alkaline solutions. The following results describe the study of the optimization of the extraction process with $\mathrm{NaOH}$ as catalyst.

\section{Effect of the ethanol/water ratio}

The dependence of the extraction yield with the solvent composition is presented in Table 1 and Figure 3. The yield of whole extracted material increased slightly with the proportion of ethanol in the mixture, in the range 0-40\% ethanol, and then increased markedly, attaining a maximum at ca. $50 \%$ ethanol. For higher ethanol proportions, the extraction yield decreased slightly again. However, as far as the extraction yield of suberin is concerned, a different pattern was observed. The efficiency for suberin removal increased with the proportion of ethanol, particularly in the range $40-100 \%$, whereas the efficiency for lignin and polysaccharides decreased in this range. Thus, although the total extraction yield reached its maximum with $50 \%$ ethanol, the selectivity for suberin extraction was highest with $100 \%$ ethanol. A tentative explanation could be related to the higher suberin affinity for ethanol compared with that for water. In ethanol-rich solutions, the penetration of the liquor into the cell wall and the subsequent hydrolysis/transesterification and dissolution of suberin, should occur more readily than with water-rich counterparts. With $100 \%$ ethanol, transesterification of the ester bonds would of course predominate over hydrolysis (it should be noted that the commercial ethanol used, certainly contained traces of water). The observed decrease in the extraction yield of lignin and polysaccharides with ethanol proportions higher than $50 \%$ was associated with the decrease of the molar fraction of water in the solution, which in turn reduced the extent of alkaline hydrolysis reactions involved in the depolymerization of lignin and polysaccharides.

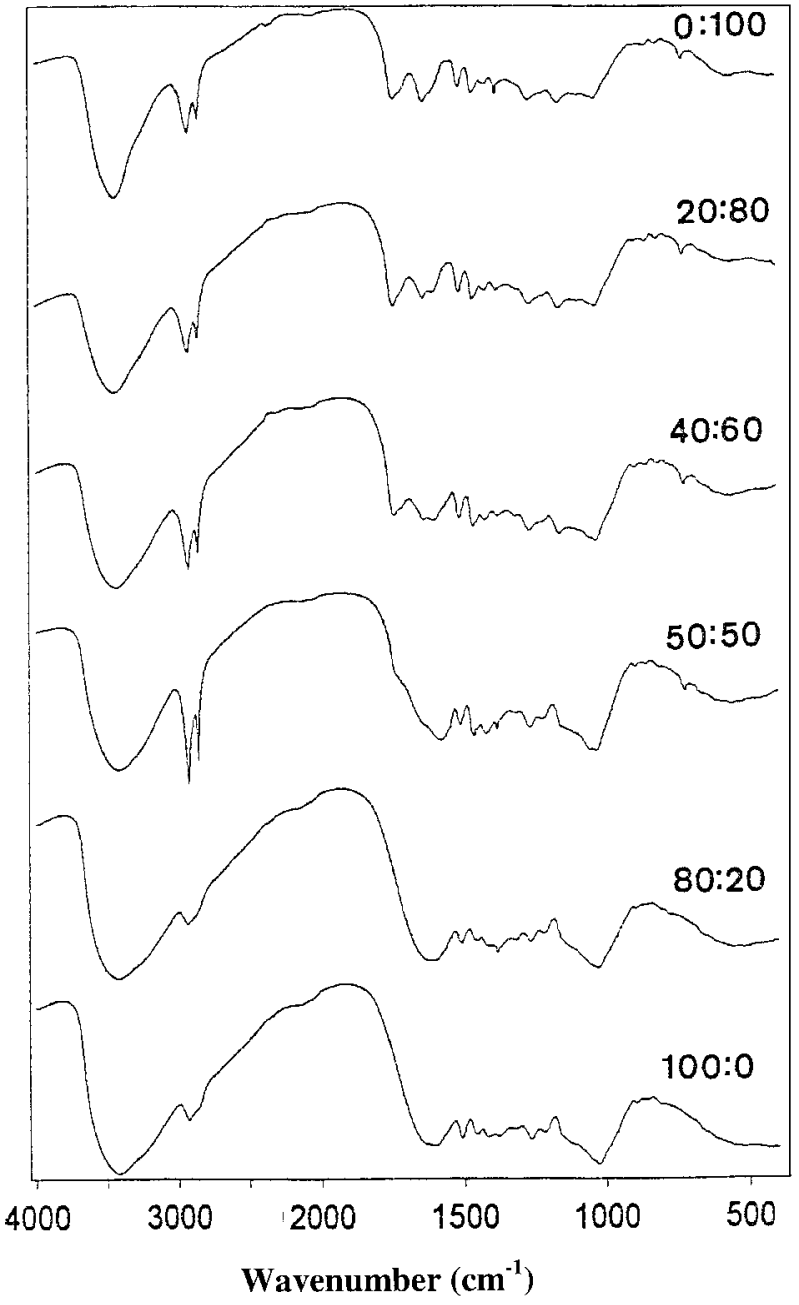

Fig. 4. FTIR spectra of residual cork from organosolv treatments carried out for $4 \mathrm{~h}$ at $160^{\circ} \mathrm{C}$, with different ethanol/water ratios, $0.1 \mathrm{M}$ sodium hydroxide and a liquor ratio of 40:1. 


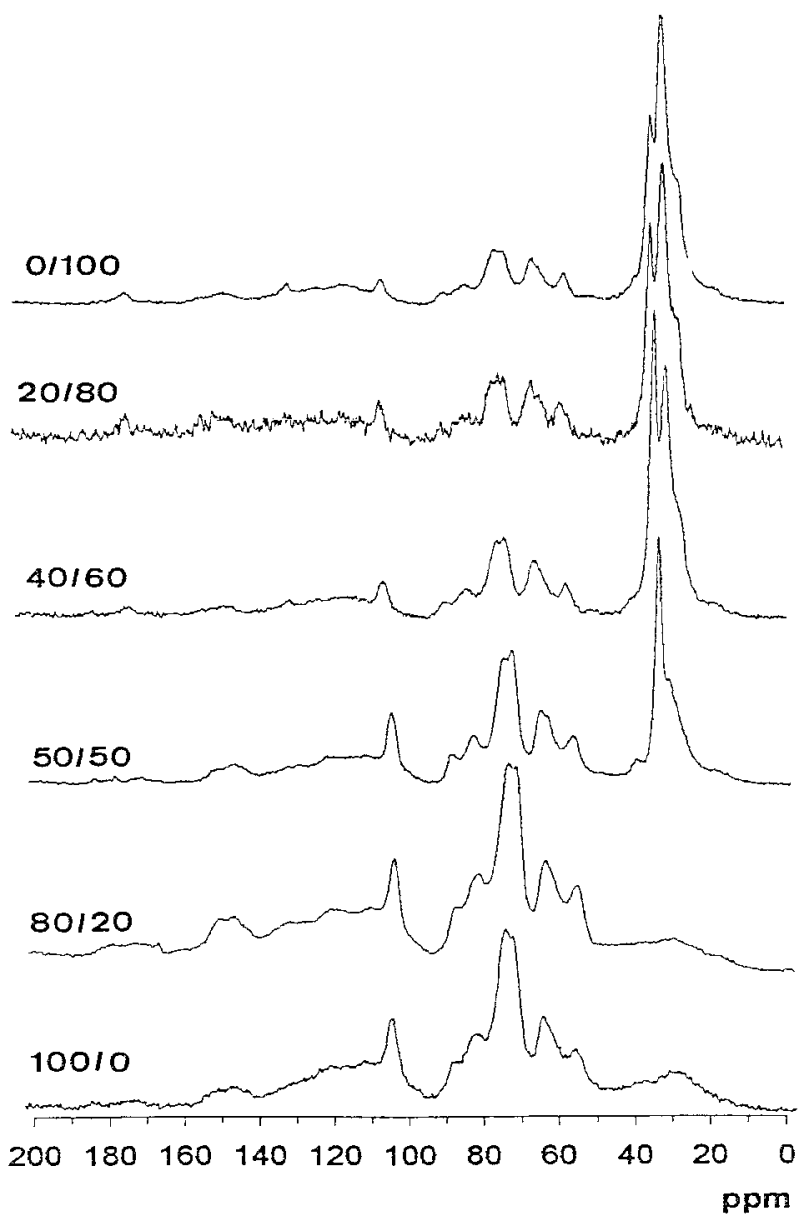

Fig. $5{ }^{13} \mathrm{C}$ NMR spectra of residual cork obtained with the conditions given in Figure 4.

Both effects were clearly confirmed by FTIR and NMR spectroscopy. Figure 4 shows the progressive decrease in the $\mathrm{CH}_{2}$ and $\mathrm{C}=\mathrm{O}$ vibrations, coming mainly from suberin, as the proportion of ethanol in the medium increased. The NMR spectra (Fig. 5) confirmed this trend by the overall effect of ethanol on the extraction of suberin, as shown by the progressive decrease in the resonances around 30 and $173 \mathrm{ppm}$ and revealed moreover a different pattern in the decrease of the peaks at 33 and $30 \mathrm{ppm}$. Indeed, the intensity ratio $\mathrm{I}_{33} / \mathrm{I}_{30}$ as a function of the medium composition showed a sharp increase between 40 and $50 \%$ ethanol content. This specific behaviour confirmed previous observations discussed above that in the cork cell wall, suberin displays two morphologies, respectively, near the polysaccharide and lignin matrix (peak at $33 \mathrm{ppm}$ attributed to less mobile methylene groups) and away from it (peak at 30 ppm for freer segments), because the latter was more easily removed than the former, which required much higher ethanol proportions. In other words, the higher the cohesive interactions binding suberin to other cork components, the harder was its detachment by the solvent, with the consequent necessity of increasing its efficiency by increasing the ethanol proportion. The effect of the composition of the ethanol/mixture on the reactivity of these two types of suberin needs further investigation.

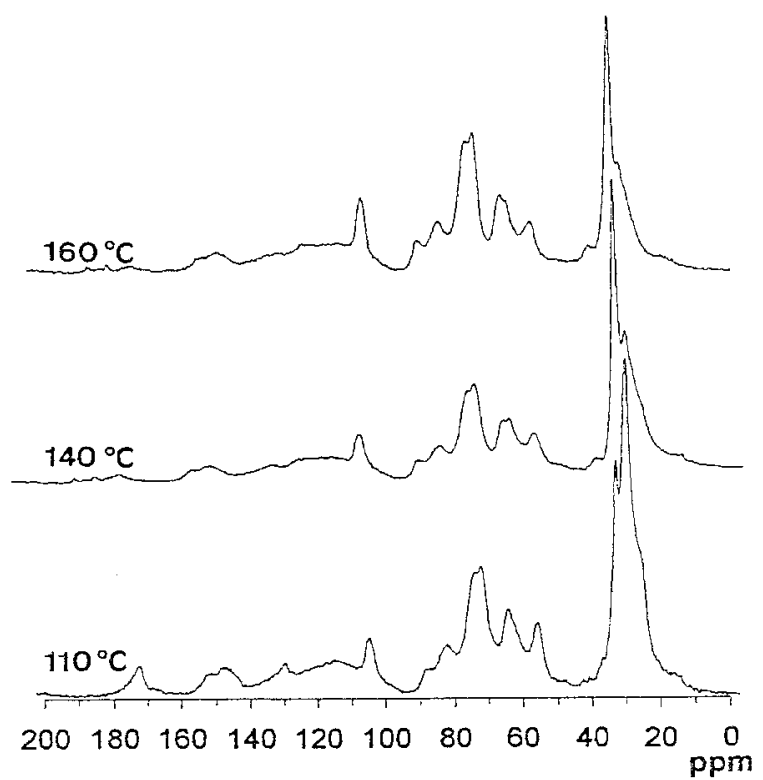

Fig. 6. ${ }^{13} \mathrm{C}$ NMR spectra of residual cork from organosolv treatments carried out for $4 \mathrm{~h}$ at $160^{\circ} \mathrm{C}$, at different temperatures, with $0.1 \mathrm{M}$ sodium hydroxide, an ethanol/water ratio of $50 / 50(\mathrm{v} / \mathrm{v})$ and a liquor ratio of 40:1.

\section{Effect of temperature}

Table 1 gives data indicating the progressive increase in extraction yield with the optimised medium, as the temperature was raised from 110 to $160{ }^{\circ} \mathrm{C}$. The FTIR and NMR spectra of the residues provided clear evidence that as the temperature increased, the proportion of tightly bound suberin extracted increased. Figure 6 shows how the different peaks attributed to the two types of suberin varied as a function of temperature. Again, the decrease in the intensity of both the $30 \mathrm{ppm}$ and $173 \mathrm{ppm}$ peaks occurred predominantly between 110 and $140{ }^{\circ} \mathrm{C}$, whereas the peak at $33 \mathrm{ppm}$ remained at a high intensity and began to decrease only at $160^{\circ} \mathrm{C}$. Again, the stronger association of the suberin sitting next to lignin and polysaccharides manifested itself by a higher resistance to extraction.

\section{Effect of $\mathrm{NaOH}$ concentration}

The increase in concentration of sodium hydroxide produced an increase in the extraction yield from $42.6 \%$ to $84.4 \%$. The results in Table 1 show that this increase was substantial below $0.1 \mathrm{M}$ and became much less pronounced above this concentration. This double regime was confirmed by the changes occurring in the FTIR and NMR spectra. Going from neutral to $0.05 \mathrm{M} \mathrm{NaOH}$ solutions produced a drastic reduction in the carbonyl vibration which disappeared already at $0.1 \mathrm{M}$ concentration. As for the NMR spectra, the virtual disappearance of the peaks at 30 and 173 ppm was again recorded between 0.05 and $0.1 \mathrm{M} \mathrm{NaOH}$, whereas the peak at $33 \mathrm{ppm}$ remained strong even at the highest $\mathrm{NaOH}$ concentration tested (Fig. 7). These results suggest again that the suberin polymers associated to the carbohydrates-lignin matrix or to the cell walls are so tightly bound, that they resist attack even by strong ethanol/water alkaline media. 


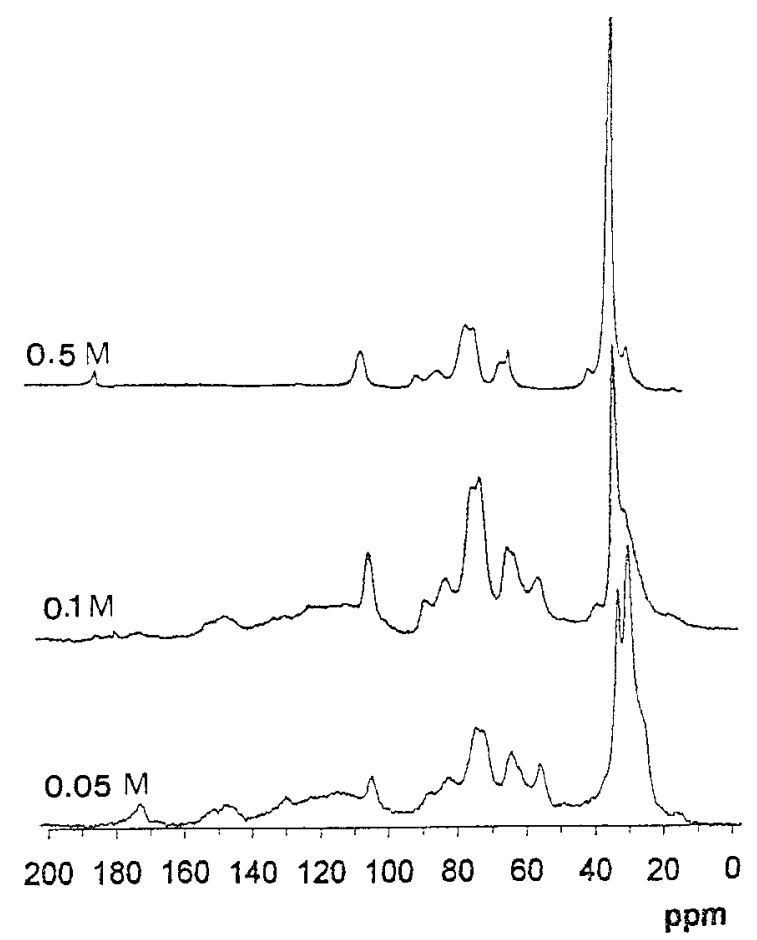

Fig. 7. ${ }^{13} \mathrm{C}$ NMR spectra of residual cork from organosolv treatments carried out for $4 \mathrm{~h}$ at $160{ }^{\circ} \mathrm{C}$, with different sodium hydroxide concentrations, an ethanol/water ratio of 50/50 (v/v) and a liquor ratio of 40:1.

\section{Effect of processing time}

Increasing the extraction time from one to four hours produced an increase in yield from $35.4 \%$ to $76.3 \%$ (Table 1). However, this change was not linear, but rather Sshaped, indicating the occurrence of an induction period, most probably associated with the diffusion of the liquid medium inside the cork structure. The FTIR and NMR spectra of the corresponding residues indicated once again that the more loosely bound suberin, placed further away from the matrix, was extracted more rapidly than its bound counterpart.

\section{Optimal extraction conditions}

On the basis of the above systematic study of the role of the main variables related to this organosolv process, the following optimised conditions are proposed concerning the best way to extract suberin (the major and most original component of this species): extraction medium ethanol; catalyst $\mathrm{NaOH}$ at a $0.1 \mathrm{M}$ concentration; temperature $160^{\circ} \mathrm{C}$; extraction time $4 \mathrm{~h}$. More severe conditions are not interesting because the extraction of suberin via the transesterification/hydrolysis of its ester linkages is accompanied by the degradation of its aliphatic chains (Cordeiro et al. 2000).

\section{Conclusions}

The results obtained in this study suggest that organosolv fractionation of cork, which was optimised through the variation of all major parameters, may be a promising alternative separation process for its components and therefore presents a major topic of interest in terms of their subsequent valorisation. The use of different catalysts led to the conclusion that basic conditions promote both high yields of extraction and the preservation of undegraded suberin. Another interesting observation was that the linkages between suberin and the carbohydrate/lignin matrix are particularly strong and can only be released under the most severe conditions. The thorough characterisation of the extracted components constitutes the logical pursuit of this investigation and is currently in progress.

\section{Acknowledgements}

The authors wish to thank the JNICT/French-Portuguese Scientific Co-operation Programme for financial support.

\section{References}

Cordeiro, N., C. Pascoal Neto, A. Gandini and M. N. Belgacem. 1995. Characterization of the cork surface by inverse gas chromatography. J. Colloid Interface Sci. 174, 246-249.

Cordeiro, N., P. Aurenty, M.N. Belgacem, A. Gandini and C. Pascoal Neto. 1996. Surface properties of suberin. J. Colloid Interface Sci. 187, 489-508.

Cordeiro, N., M. N. Belgacem, A. Gandini and C. Pascoal Neto. 1997. Urethanes and polyurethanes from suberin. 1. Kinetic study. Industrial Crops and Products 6, 163-167.

Cordeiro, N. 1998. Fraccionamento da cortiça y caracterizaçao dos seus componentes. Doctorate Thesis, University of Aveiro, Portugal, pp. 57-137.

Cordeiro, N., M. N. Belgacem, A. J. D. Silvestre, C. Pascoal Neto and A. Gandini. 1998 a. Cork suberin as a new source of chemicals. 1. Isolation and chemical characterization of its composition, Int. J. Biol. Macromol. 22, 71-82.

Cordeiro, N., M. N. Belgacem, A. Gandini and C. Pascoal Neto. 1998 b. Cork suberin as a new source of chemicals. 2. Crystallinity, thermal and rheological properties. Bioresource Technology 63, 153-158.

Cordeiro, N., M. N. Belgacem, A. Gandini and C. Pascoal Neto. 1999. Urethanes and polyurethanes from suberin: 2 . Synthesis and characterization. Industrial Crops and Products 10,1-10.

Cordeiro, N., A. Blayo, M. N. Belgacem, A. Gandini, C. Pascoal Neto and J.F. Le Nest. 2000. Cork suberin as an additive in offset printing inks. Industrial Crops and Products 11, 63-71.

Evtuguin, D. V., I. P. Deineko and C. Pascoal Neto. 1999. Oxygen delignification in aqueous organic solvents media. Cell. Chem. Technol. 33, 103-123.

Garbow, J. R., L. M. Ferrantello and R. E. Stark. 1989. ${ }^{13}$ C nuclear magnetic resonance study of suberized potato cell wall. Plant physiol. 90, 783-787.

Gil, A. M., M. Lopes, J. Rocha and C. Pascoal Neto. 1997. Study of molecular structure and dynamics of cork suberin by solid state ${ }^{13} \mathrm{C}$ nuclear magnetic resonance spectroscopy. Int. J. Biol. Macromol. 20, 293-305.

Lopes, M., C. Pascoal Neto, D. Evtuguin, A. Silvestre, N. Cordeiro and A. Gandini. 1998. Products of permanganate oxidation of cork, desuberized cork, suberin and lignin. Holzforschung 52, 146-148.

Lopes, M. H., A. Gil, A. J. D. Silvestre and C. Pascoal Neto. 2000. Composition of suberin extracted upon gradual alkaline methanolysis of Quercus suber L. cork. J. Agric. Food Chem. $48,383-391$.

Lora, J.H. and S. Aziz. 1985. Organosolv pulping: A versatile approach to wood refining. Tappi J. 68(8), 74-82. 
Marques, A. V., H. Pereira, D. Meier and O. Faix. 1996. Quantitative Analysis of cork (Quercus suber L.) and milled cork lignin by FTIR spectrometry. Holzforschung 48, 43-50.

Pascoal Neto, C., D. Evtuguin and A. Robert. 1994. Chemicals generated during oxygen-organosolv pulping of wood. J. Wood Chem. Techn. 14, 383-402.

Pascoal Neto, C., J. Rocha, A. Gil, N. Cordeiro, A. Esculcas, J. P. Pedrosa de Jesus, S. Rocha, I. Delgadillo and A. J. Ferrer Correia. 1995. Solid-state nuclear magnetic resonance and Fourrier transform infrared studies of thermal decomposition of cork. Solid State NMR 4, 143-151.

Pascoal Neto, C., N. Cordeiro, A. Seca, F. Domingues, A. Gandini and D. Robert. 1996. Isolation and characterization of a ligninlike polymer of cork of Quercus suber L. Holzforschung 50, 563-565.

Pereira, H. 1988. Chemical composition and variability of cork from Quercus suber L. Wood Sci. Technol. 22, 211-218.

Stark, R. E. and J. R. Garbow. 1992. Nuclear magnetic resonance relaxation studies of plant polyester dynamic. 2. Suberized potato cell wall. Macromolecules 25, 149-154.

Zlotnik-Mazori, T. and R. E. Stark. 1988. Nuclear magnetic resonance studies of cutin, an insoluble plant polyester. Macromolecules 21, 2412-2417.
Received October $5^{\text {th }} 2000$

Nereida Cordeiro

Universidade da Madeira

Centro de Investigação em Ciências Agrárias, (CICA).

9000 Funchal

Portugal

Carlos Pascoal Neto

Joao Rocha

Universidade de Aveiro

Departamento de Química

3810 Aveiro

Portugal

Mohamed N. Belgacem

Alessandro Gandini ${ }^{1)}$

Ecole Française de Papeterie et

des Industries Graphiques (INPG)

BP 65

38402 St. Martin d'Hères cedex

France

1) Corresponding author

(E-mail: Alessandro.Gandini@efpg.inpg.fr) 